\title{
MOSQUITO INVESTIGATIONS IN ALASKA
}

\author{
By GeORge S. TULLOCH \\ Brooklyn College, Brooklyn, N. Y.
}

During the summer of 1931 the United States Department of Agriculture and the United States Smelting Refining and Mining Company entered into a coöperative agreement in connection with investigations as to the "habits, biology and methods of control of mosquitoes in Alaska". The writer was employed by the United States Smelting Refining and Mining Company to carry on the investigations under the technical direction of F. C. Bishopp of the Bureau of Entomology. The investigations were carried on in the vicinity of Fairbanks, Alaska, with headquarters at the Fairbanks Exploration Company, a subsidiary of the United States Smelting Refining and Mining Company. Laboratory quarters (Fig. 1) were located at Fox, eleven miles northeast of Fairbanks.

The purpose of the investigations was to determine if practical control methods could be suggested which would reduce the annoyance of mosquitoes to men engaged in gold mining operations. In this region workmen must protect themselves from the attacks of these pests. Nets (Fig. 2) and gloves or similar means of protection (Fig. 3) serve this purpose during the periods in which mosquitoes are abundant. Although mosquito investigations have been carried on in many parts of the world, it is believed that this was the first attempt to study the control of mosquitoes in a practically arctic environment.

The area in which the investigations were carried on lies between $64^{\circ}-10^{\prime}$ and $64^{\circ}-50^{\prime}$ north latitude and between $147^{\circ}-20^{\prime}$ and $147^{\circ}-20^{\prime}$ and $147^{\circ}-50^{\prime}$ west longitude in the $\mathrm{Yu}$ kon-tanana region which forms a part of the central plateau of Alaska. Mr. James Crawford, research engineer of the 


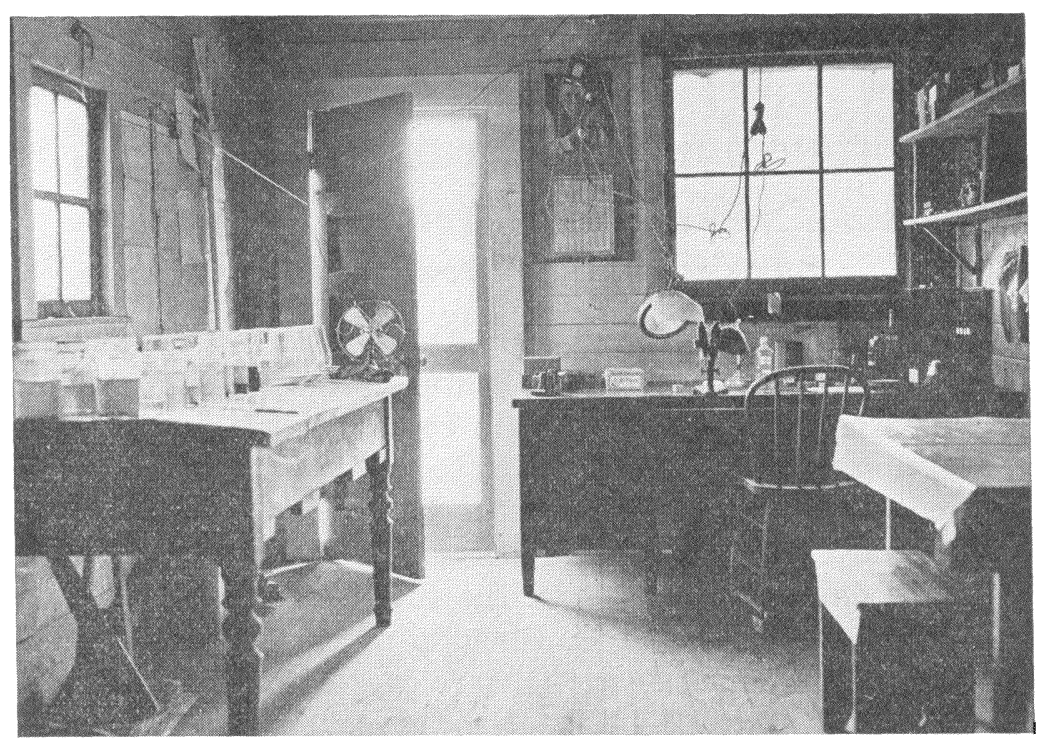

Fig. 1. Laboratory Quarters at Fox, Alaska

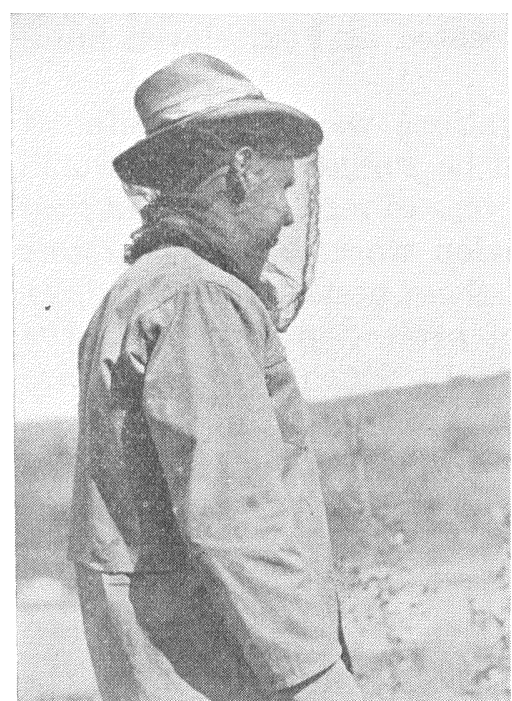

Fig. 2. Net used as protection against mosquitoes

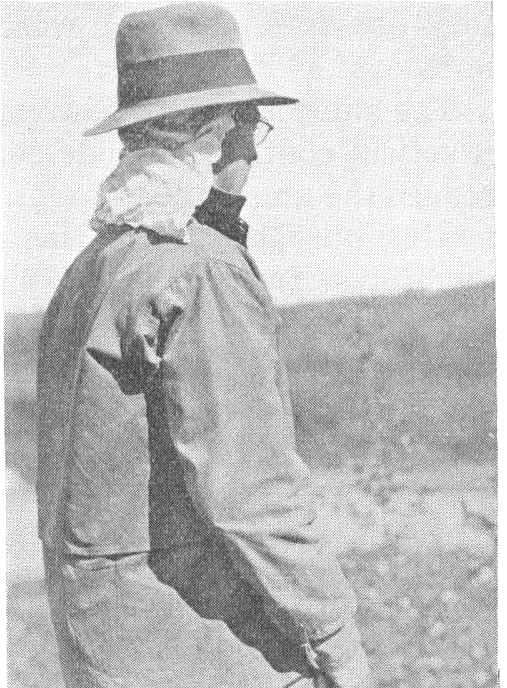

Fig. 3. Use of gloves as protection against mosquitoes 
Fairbanks Exploration Company, has described the general region as follows:

"The region may be described as a plateau, with bed rock composed predominantly of schists, which has been cut by numerous streams and their tributaries. Comparatively broad unsymmetrical valleys with broad interstream areas are characteristic. Isolated prominences, locally known as

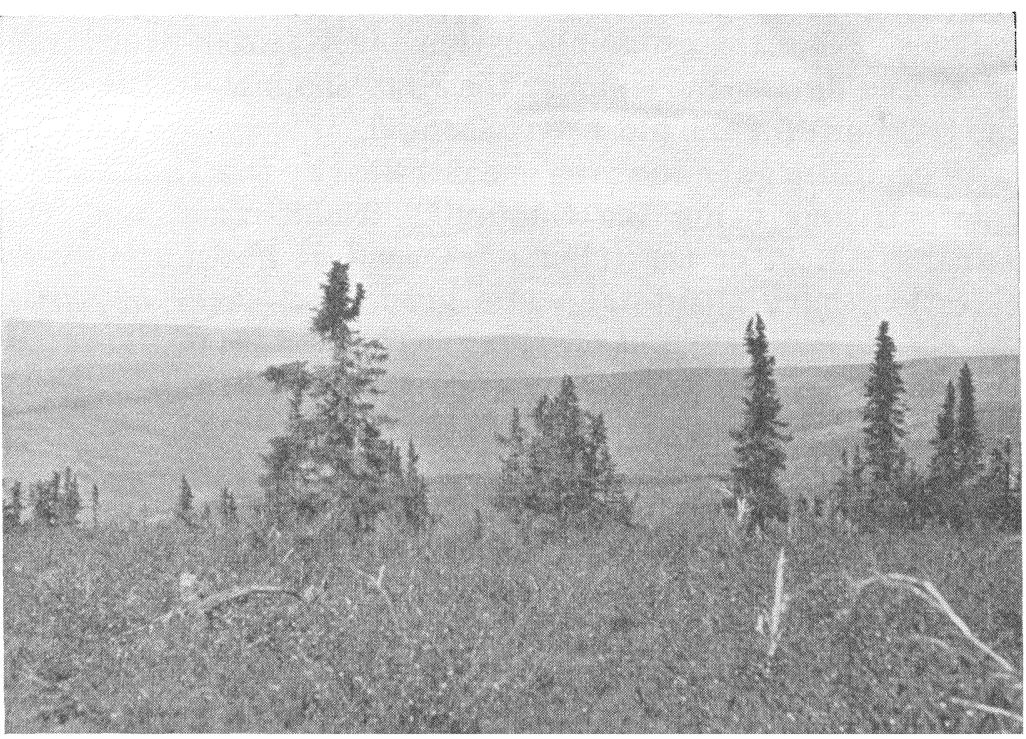

Fig 4. Characteristic view of country in the region where mosquito investigations were made

domes, which are composed of igneous rocks and owe their presence to the resistance of such rocks to weathering, rise above the general level of the neighboring ridges (Fig. 4). The average elevation of the ridges is around 2000 feet above sea level, while that of the valleys varies from 470 feet at Fairbanks to 940 feet in the valley of Goldstream at Gilmore."

"The region has been subjected to long continued and intricate stream modeling and since it lies outside the area of 
glaciation, its topography is due almost exclusively to stream erosion. A mantle of 'muck', in part decomposed organic material, covers the hillsides and the unconsoligated gravel deposits in the valleys. This mantle is in turn covered by varying thicknesses of moss on the hillside, which is combined with bunch grass, locally known as 'niggerheads' in the valleys. Spruce trees grow extensively on the side hill while clumps of birches, willows and alders are found in the valleys. Since the ground is permanently frozen over large areas and during the summer thaws to shallow depths only, the trees are for the most part stunted."

"The drainage in the area is controlled by the Tanana, the chief streams being the Chatanika, Goldstream, and the Tanana. Most of the tributaries head at about the same elevation, have about the same grade and carry approximately the same amount of water. The courses of the small tributary streams are well defined and definite throughout their lengths, however, drainage conditions in the flat portion of the valleys traversed are poor, due in part to frozen ground and vegetation. In most of the valleys shallow swamps interspersed with 'niggerheads' stand above the general elevation of the stream. In the broad valleys such as those of the Chatanika and Goldstream, large areas of such swamps are present. ****."

The climate of the interior of Alaska is characterized by extremes in temperature and light precipitation. The socalled "interior" of Alaska is the drainage system of the Yukon River with its tributaries, the Koyukuk, Chandalar, Tanana, Kantishna and Porcupine Rivers. This region lies well to the north of the Gulf of Alaska and the Aleutian chain of islands. It is well known that the vicinity of The Alaska Peninsula is a continuous low pressure area and a breeding place for storms. The cyclones and anti-cyclones occurring in this region move eastward across the Gulf and follow several established routes across the United States and Southern Canada. The offshoots from these lows rarely affect the climate of the interior, although they 
cause storms and precipitation on the southern slopes of the Alaska Range. Occasionally a low pressure area will move through the interior, coming up from the Bering Sea. These give southerly winds throughout the interior. During the summer the heated interior of Alaska is conducive to low pressure areas of slight intensity which, in turn, induce precipitation.

The precipitation over the greater part of the interior is small. Around Fairbanks it averages from 10 to 14 inches. About $25 \%$ of this occurs in the form of snow. Normally the wettest months are July and August with June and September following. These four receive over half the year's precipitation. Over a period of 15 years the records show that the wettest years gave over twice the precipitation of the dry years. This disparity is due largely to the excess of rainfall in the summer months of the wet years and a deficiency of rainfall in dry years rather than marked changes from normal in other months. Around Fairbanks snow is usually gone by the last of April, although an occasional fall of snow in May or June is not uncommon. During the summer months rainfall is sometimes attended by mild thunderstorms and sometimes hail.

The summers of interior Alaska have delightful temperature conditions. They are warm enough for comfort, but are not oppressively hot. The long days and continuous sunshine cause rapid growth of vegetation. The highest temperature ever recorded over many years was $100^{\circ} \mathrm{F}$. at Fort Yukon in July, 1915. The spring months have the highest percentage of possible sunshine and the late fall and the early winter months the least. Fairbanks averages 17 clear days in April and only 8 in September. Winter temperatures are as low as $75^{\circ} \mathrm{F}$.

The situations in which mosquito larvæ were found developing fall into two fairly well defined categories. The first included those areas in which the water was present during the greater part of the summer while the second included those areas in which the pools were temporary in 
nature. Prospect shafts and permanent swampy areas are included in the first category while the surface pools found in the moss and in the "niggerheads" are included in the second category.

The larvæ found to be peculiar to the permanent breeding areas represented two species, Culiseta alaskænsis and Culex apicalis. The larvæ of the first species appeared during the latter part of the season having developed from eggs laid by the overwintering females. The larvæ of the second species were found earlier in the season, having developed from overwintering eggs. The adults of $C$. alaskænsis although they were present in great numbers during the early part of the season of 1931 did not cause any great annoyance to the workmen.

The following species appear to be represented in the material collected during 1931:

\section{TABLE I}

1. Anopheles maculipennis Meigen

Adult

2. Culiseta alaskænsis Ludlow

3. Culiseta impatiens Walker

4. Aëdes diantæus $\mathrm{H}$. D. and $\mathrm{K}$.

5. Aëdes communis Felt and Young

6. Aëdes fitchii H. D. and K.

7. Aëdes punctor Kirby

8. Aëdes aldrichi Dyar

9. Aëdes cyclocerculus Dyar

10. Aëdes leuconotips Dyar

11. Aëdes impiger Walker

12. Aëdes aboriginis Dyar

13. Aëdes stimulans Walker

14. Aëdes cataphylla Dyar

Larva and Adult

Adult

Larva

Larva and Adult

Larva

Larva and Adult

Larva and Adult

Larva

Larva

Larva

Larva and Adult

Larva and Adult

Adult

15. Culex apicalis Adams

Larva and Adult

16. Eucorethra underwoodii Underwood

17. Chaoborus trivittatus Loew

Larva and Adult

Larva

18. Corethra sp.

Larva and Adult 
The mosquitoes found to be developing in the temporary situations represented several species, many of which were troublesome. The water in these pools resulted from two sources, the more important of these being the melting of the snow. The subsequent accumulation of water in small pools provided excellent breeding places for the development of the larvæ from the overwintering eggs. The second source was not of as much consequence, being the result of the thawing of the frozen ground; the water rising to the surface and forming new pools or adding to the pools which had resulted from the melting of the snow. During some seasons it is possible that the rainfall during April and May may result in the formation of pools similar to those formed by the melting snow. Such a condition did not exist during 1931; water from rainfall acted in a contributory capacity, viz., replenished pools so that the water remained long enough to allow larvæ to complete their normal development.

Although the number of species present was rather large only four, A. punctor, A. communis, A. aldrichi and A. stimulans were present in large numbers. As far as is known, the life histories of these four species are very similar, the general description which follows being equally applicable to all. The eggs are laid in summer on moist or dry ground and remain unhatched until after having been exposed to winter cold. Early in the spring when rising temperatures cause the accumulated snow and ice to melt forming pools on the frozen ground, the eggs hatch and the first stage larvæ appear. During 1931 some larvæ reached maturity early in June, pupation being first noted on June 8. Adults of $A$. communis, $A$. punctor, and $A$. aldrichi appeared about the same time in the middle of June and were present in noticeable numbers throughout the same period (Table 2) during the season. A stimulans appeared somewhat later and was present in numbers throughout a longer period than the other three. Information pertaining to the distribution and relative abundance of these troublesome species was col- 
lected by the timekeepers at four different stations in the gold dredging area. The method employed was to have each timekeeper make a five minute collection at the same time and the same place each day. Specimens were sent in for identification on Saturday of each week. The results from one of these collection points are tabulated below. These results are similar to others collected from other stations except in a few minor details.

\section{TABLE II}

Number of specimens of different species taken in five minute collections on man at Gilmore, Alaska.

\begin{tabular}{|c|c|c|c|c|c|c|c|c|}
\hline Date & $\begin{array}{l}\text { No. of } \\
\text { speci- } \\
\text { mens }\end{array}$ & $\begin{array}{l}\text { Aedes } \\
\text { com- } \\
\text { mu- } \\
\text { nis }\end{array}$ & $\begin{array}{l}\text { Aedes } \\
\text { punc- } \\
\text { tor }\end{array}$ & $\begin{array}{l}\text { Aedes } \\
\text { ald- } \\
\text { richi }\end{array}$ & $\begin{array}{l}\text { Aedes } \\
\text { stim- } \\
\text { ulans }\end{array}$ & $\begin{array}{l}\text { Culi- } \\
\text { seta } \\
\text { alaska- } \\
\text { ensis }\end{array}$ & $\begin{array}{l}\text { Ano- } \\
\text { pheles } \\
\text { maculi } \\
\text { pennis }\end{array}$ & $\begin{array}{l}\text { Un- } \\
\text {-iden- } \\
\text { tified* }\end{array}$ \\
\hline $6-17$ & $\ldots 20$ & 4 & & 6 & & 1 & 1 & 8 \\
\hline $6-18$ & $\ldots 11$ & 7 & & & & & & 4 \\
\hline $6-19$ & $\ldots 16$ & 5 & & 1 & & & & 10 \\
\hline $6-20$ & $\ldots$ & & & & 1 & 2 & & \\
\hline $6-21$ & $\ldots 30$ & 3 & 7 & & 1 & & & 19 \\
\hline $6-22$ & $\ldots$ & & & & & & & 3 \\
\hline $6-23$ & $\ldots 20$ & & & & & 2 & & 18 \\
\hline $6-24$ & $\ldots 20$ & 2 & & & & & & 18 \\
\hline $6-27$ & $\ldots 8$ & & 1 & & & & & 7 \\
\hline $6-28$ & $\ldots 15$ & 1 & & & 1 & 1 & & 12 \\
\hline $6-29$ & $\ldots 6$ & & & & 2 & & & 4 \\
\hline $6-30$ & $\ldots 2$ & & & & 1 & & & 1 \\
\hline $7-2$ & $\ldots \quad 4$ & & & & 3 & & & 1 \\
\hline $7-3$ & $\ldots 4$ & & & 1 & 3 & & & \\
\hline $7-6$ & $\ldots 8$ & & & & 5 & & & 3 \\
\hline $7-7$ & $\ldots$ & & & & 5 & & & 2 \\
\hline $7-8$ & $\ldots$ & & & & & & & 4 \\
\hline $7-16$ & $\ldots$ & & & & 3 & & & \\
\hline $7-18$ & $\ldots 3$ & & & & 2 & & & 1 \\
\hline $8-11$ & $\ldots$ & & & & 4 & & & \\
\hline $8-12$ & $\ldots 2$ & & & & 2 & & & \\
\hline $8-13$ & $\ldots$ & & & & 5 & & & \\
\hline $8-14$ & $\ldots$ & & & & 4 & & & \\
\hline $8-15$ & $\ldots$ & & & & 5 & & & \\
\hline $8-16$ & $\ldots$ & & & & 4 & & & \\
\hline $8-17$ & $\ldots$ & & & & 5 & & & 1 \\
\hline
\end{tabular}

*Specimens damaged during collection. 
Although no detailed study of the various natural factors controlling the abundance of mosquitoes was made, the following observations were made which indicated that considerable numbers of mosquitoes were destroyed by predacious insects and other enemies. Larvæ of Dytiscid and Hydrophilid beetles were abundant as well as backswimmers, all of which are known to be efficient enemies of mosquito larvæ. The predacious larvæ of three species of mosquitoes (Table 1) were found in large numbers and birds and amphibians reputed to prey upon the larva or adult mosquito were present also in this region.

It was a generally admitted fact that the mining operations themselves have aided in abating the nuisance from mosquitoes. The removal of the surface moss and muck and the dredging operations have reduced the extent of the breeding areas. The removal of brush has reduced the extent of the natural environment preferred by the troublesome adults and driven them away from the vicinity of the workmen. As a result of these two operations the conditions in certain localized areas have been improved greatly. At the conclusion of the investigation in 1931 specific recommendations were made relative to further improving the conditions near the mining operations.

As indicated before the major portion of the breeding during 1931 was in the pools in the moss and the niggerheads situated in the lower level portions of the valleys, These pools are usually covered partly or entirely with dead grass and moss from the previous year. The presence of this dead vegetation retards the evaporation of water as well as impedes the drainage. It was recommended that all the dead grass and moss around the operations be removed by burning during the spring of the year. This recommendation was prompted by the observation that an area of about one hundred acres which had been fired accidentally contained relatively few pools containing larvæ while in the adjacent unburned areas larvæ were abundant in the pools. Other recommendations included oiling and draining of 
pools within 500 yards of the operations, the use of copper sulphate as a larvicide and the use of repellants by the workmen. Control work was carried on during 1932 under the direction of Mr. J. D. Crawford. In the report at the end of the season, Mr. Crawford recommended that the work be continued during the season of 1933 . 

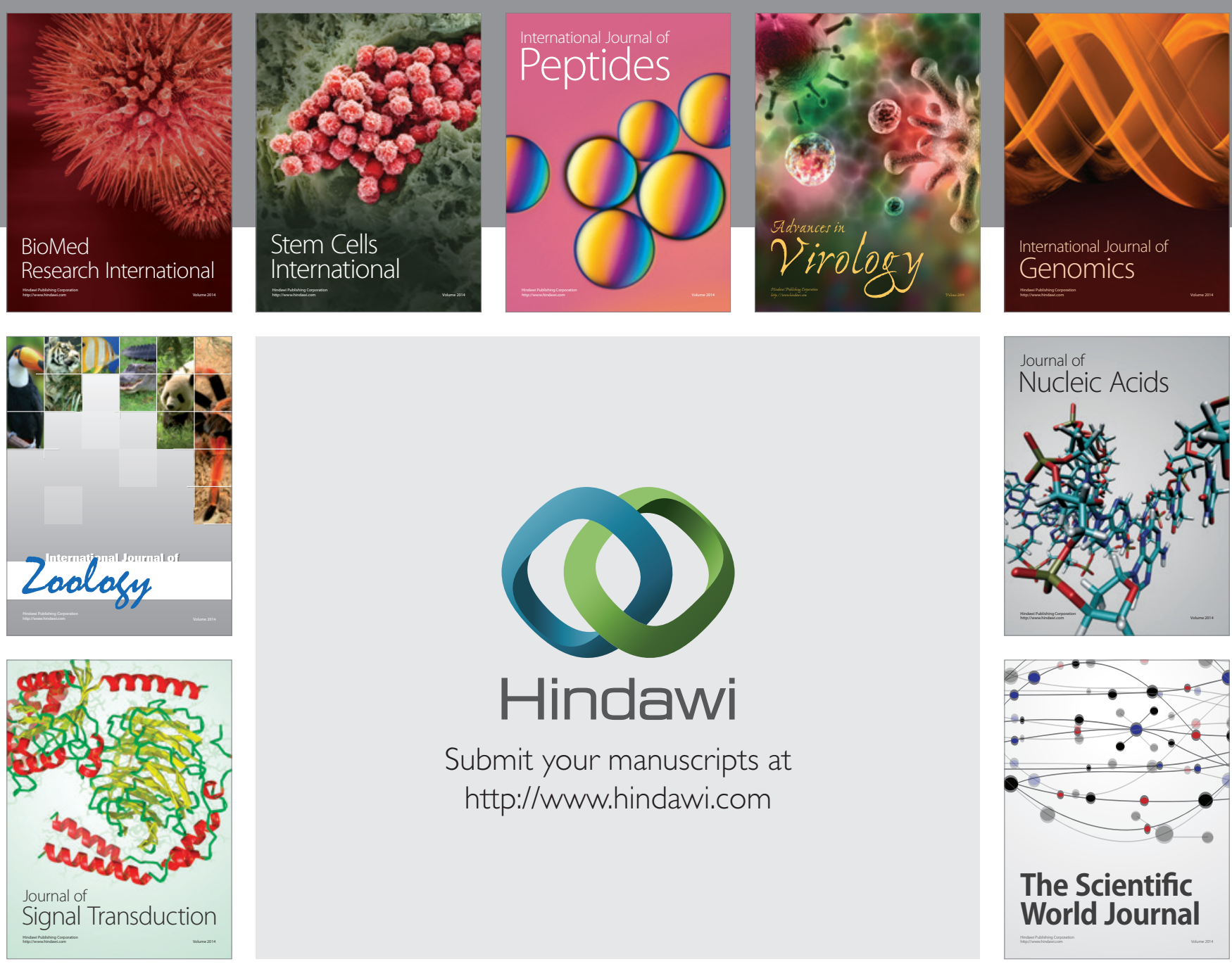

Submit your manuscripts at

http://www.hindawi.com
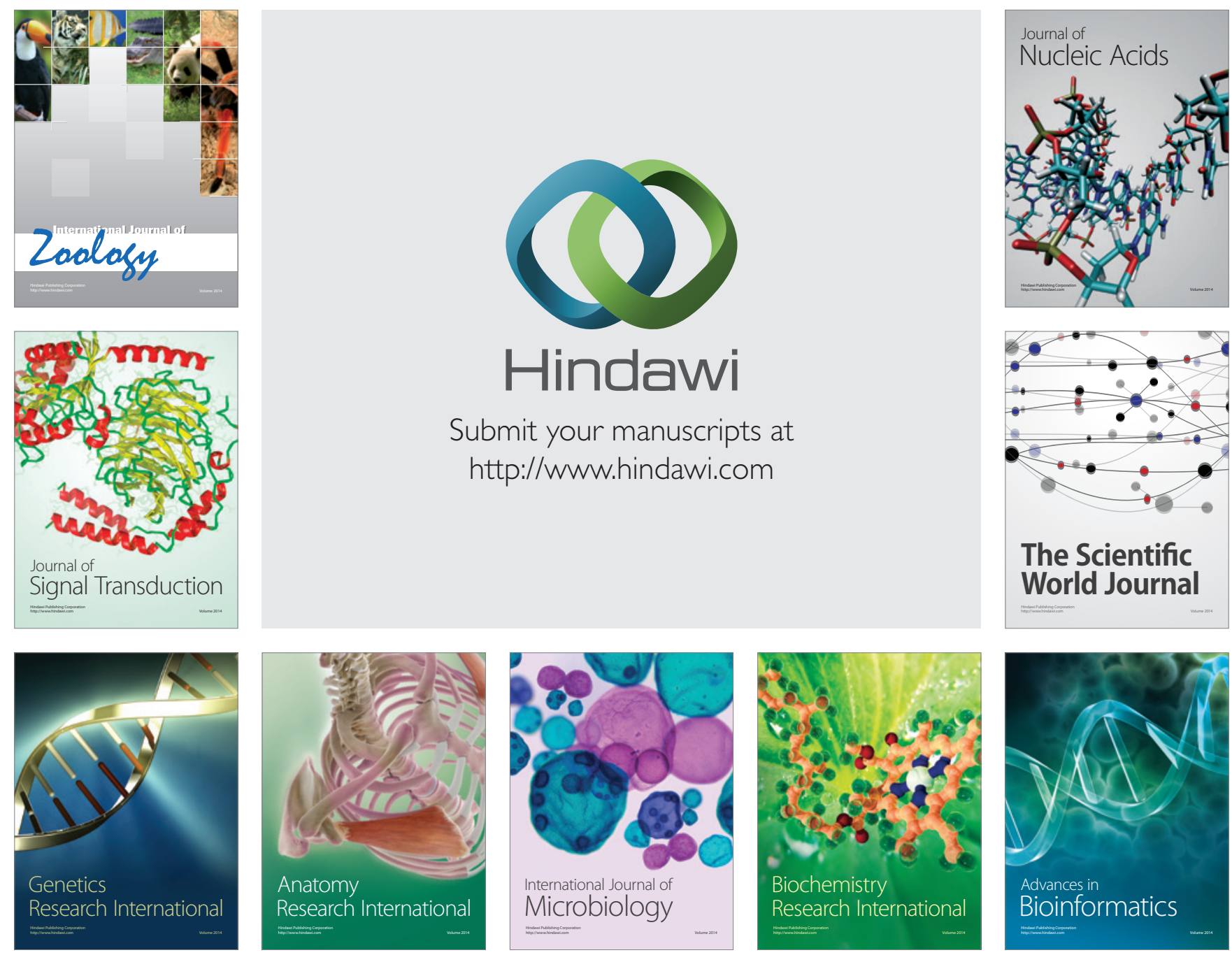

The Scientific World Journal
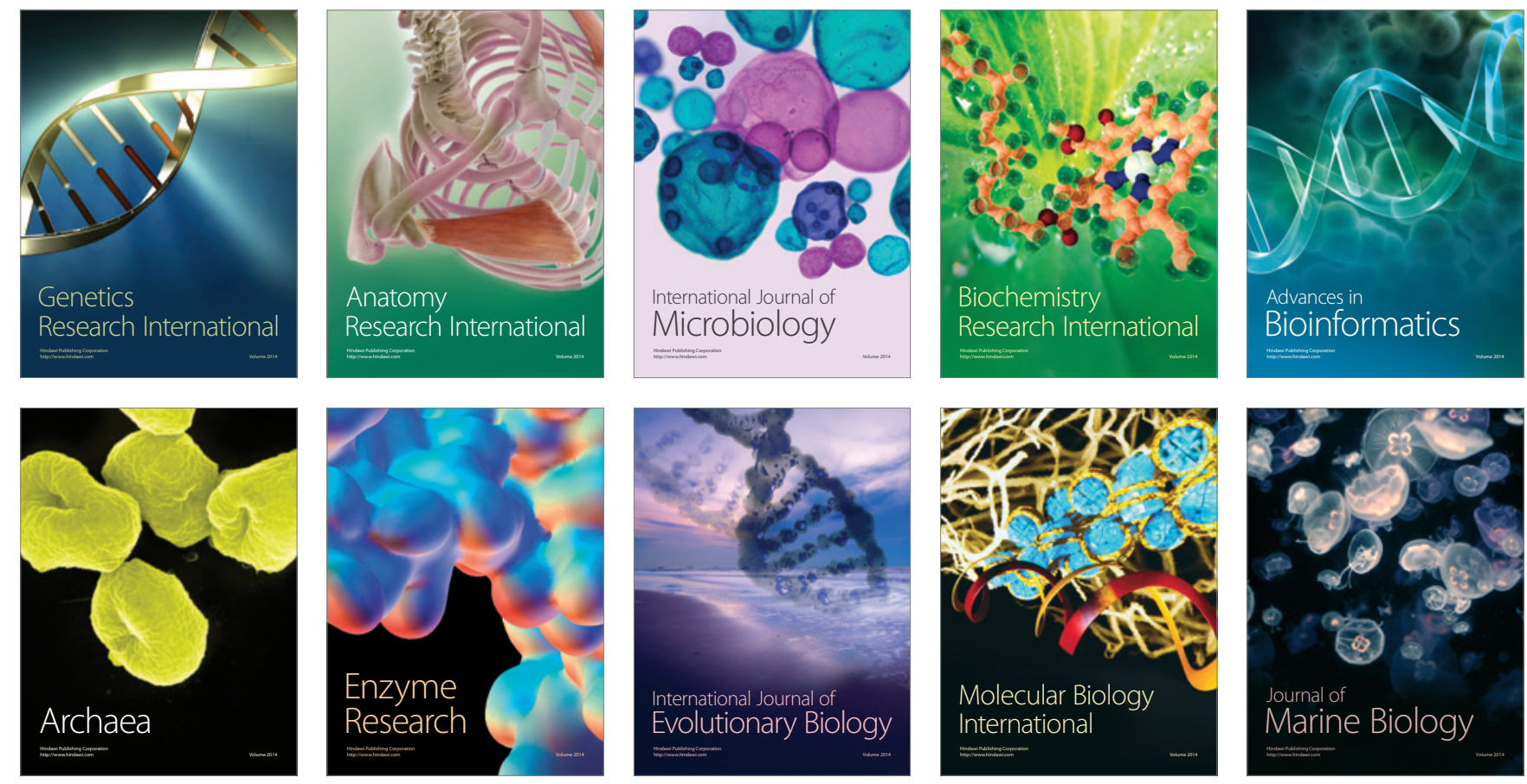